\title{
Producing hydrogen from wastewater sludge by Clostridium bifermentans
}

\author{
C.C. Wang ${ }^{\mathrm{a}}$, C.W Chang ${ }^{\mathrm{a}}$, C.P. Chu ${ }^{\mathrm{a}}$, D.J. Lee ${ }^{\mathrm{a}, *}$, B.-V. Chang ${ }^{\mathrm{b}}$, C.S. Liao ${ }^{\mathrm{b}}$ \\ a Department of Chemical Engineering, National Taiwan University, Taipei 10617, Taiwan \\ ${ }^{\mathrm{b}}$ Department of Microbiology, Soochow University, Taipei 111, Taiwan
}

Received 16 August 2002; received in revised form 9 December 2002; accepted 11 December 2002

\begin{abstract}
Excess wastewater sludge collected from the recycling stream of an activated sludge process is biomass that contains large quantities of polysaccharides and proteins. However, relevant literature indicates that the bio-conversion of wastewater sludge to hydrogen is limited and therefore not economically feasible. This work examined the anaerobic digestion of wastewater sludge using a clostridium strain isolated from the sludge as inoculum. A much higher hydrogen yield than presented in the literature was obtained. Also, the effects of five pre-treatments-ultrasonication, acidification, sterilization, freezing/thawing and adding methanogenic inhibitor - on the production of hydrogen were examined. Freezing and thawing and sterilization increased the specific hydrogen yield by $1.5-2.5$ times to that of untreated sludge, while adding an inhibitor and ultrasonication reduced the hydrogen yield.
\end{abstract}

(C) 2003 Elsevier Science B.V. All rights reserved.

Keywords: Hydrogen; Sludge; Fermentation; Pre-treatment

\section{Introduction}

Hydrogen is a clean source of energy. The anaerobic conversion of biomass has been demonstrated as a technically feasible way of generating hydrogen. The substrates used include highstrength wastewater (Bolliger et al., 1985; Liu et al., 1995; Ueno et al., 1996; Zhu et al., 1999), solid waste (Lay et al., 1999; Mizuno et al., 2000b) or certain aqueous solutions, such as those of molasses (Tanisho and Ishiwata, 1994), glucose (Ka-

\footnotetext{
* Corresponding author. Fax: +886-2-2362-3040.

E-mail address: djlee@ccms.ntu.edu.tw (D.J. Lee).
}

taoka et al., 1997; Lin and Chang, 1999), crystalline cellulose (Lay, 2001), peptone (Bai et al., 2001) and starch (Lay, 2000). Various ways of enhancing hydrogen production have been reported (Tanisho and Ishiwata, 1995; Sparling et al., 1997; Tanisho et al., 1998; Liang et al., 2001; Mizuno et al., 2000a). During anaerobic digestion, methanogenic or sulfate-reducing bacteria consume hydrogen produced by acidogenic bacteria, contributing negatively to bio-hydrogen production (Mizuno et al., 2000a). Effectively extracting hydrogen from an anaerobic reactor depends on special procedures to block out the co-metabolic chains (Adams and Stiefel, 1998). A low partial pressure of hydrogen in the vapor phase promotes 
acidogenic dehydrogenation and methanogenesis (Guwy et al., 1997; Gurijala et al., 2000; Mizuno et al., 2000a).

Table 1 lists some results from the literature. Various means of producing hydrogen using numerous substrates and seed bacteria have been reported, such as $\mathrm{g}-\mathrm{H}_{2} / \mathrm{g}$-VSS (volatile suspended solids), $\mathrm{ml}-\mathrm{H}_{2} / \mathrm{g}$-COD (chemical oxygen demand) and others. Experimental results can almost never be compared because details for unit conversion are unavailable. Certain assumptions were made to convert the data presented in Table 1 for comparison. The production of bio-hydrogen mostly ranges from 5 to $10 \mathrm{mmol}-\mathrm{H}_{2} / \mathrm{g}$-dried solids (DS) for glucose and $1-1.5 \mathrm{mmol}^{-\mathrm{H}_{2}} / \mathrm{g}$-DS for protein-containing water.

Waste-activated sludge from a wastewater treatment plant contains high levels of organic matter and thus are a potential substrate for producing hydrogen. Very few studies have addressed this topic. Limited data show that the bio-hydrogen yield using waste activated sludge and anaerobic fermentation is rather low at $\approx 0.08 \mathrm{mmol}-\mathrm{H}_{2} / \mathrm{g}$ DS (Huang et al., 2000). Pre-treatment can increase the efficiency of anaerobic stabilization of sludge by hydrolyzing the insoluble organic matter to water (e.g. see Lee and Mueller (2001) and the references cited therein). The use of thermal boiling to hydrolyze sludge has been demonstrated to promote the anaerobic production of methane (Chu et al., 2002a). Cheng et al. (2000) reported a yield of $0.7 \mathrm{mmol}^{-\mathrm{H}_{2}} / \mathrm{g}-\mathrm{COD}$ by anaerobically fermenting the thermally boiled waste-activated sludge. This value is close to that obtained for fermenting protein-containing wastewater, but is still much lower than that for polysaccharides. Cheng et al. (2000) also noted a time lag of $66 \mathrm{~h}$ for the microbes to adapt themselves to produce hydrogen from the boiled sludge. The production of hydrogen from waste sludge does not seem very promising, given the low yields reported in these preliminary studies.

Systematic studies of the anaerobic fermentation of wastewater to produce hydrogen are still lacking. This work used clostridium strains isolated from the collected wastewater sludge as an inoculum to produce hydrogen, using the sludge itself as the substrate. Apart from the thermal boiling employed by Cheng et al. (2000) to pre-treat the sludge, the effects of common pretreatment processes on hydrogen conversion are yet to be examined, including treatment with acid (Jean et al., 2000), ultrasound (Chu et al., 2002b) and freezing and thawing (Chu et al., 1999). The impact of five different sludge pre-treatment processes on hydrogen yields is examined here.

\section{Experimental}

\subsection{Substrate}

Wastewater sludge was taken from the recycled stream of the secondary treatment stage of MinSheng Municipal Wastewater Treatment Plant in Taipei, which handles $15000 \mathrm{t}$ wastewater daily. The collected sample settled under the influence of gravity to yield a solids content of $16500 \mathrm{mg}^{-1}$ and was the substrate in testing. The $\mathrm{pH}$ value of the sludge was $\approx 6.4$. The chemical oxygen demand (COD) of the sludge was $24800 \mathrm{mg} \mathrm{1}^{-1}$, measured directly from a spectrometer (DR/2000, Hach, USA). The COD of the filtrate of the sludge sample obtained after filtering through a $0.45-\mu \mathrm{m}$ membrane, called soluble COD (SCOD), was 339 $\mathrm{mg} 1^{-1}$ for the original sludge. The elemental compositions of the dried sample were C: $34.2 \%$, $\mathrm{H}: 5.3 \%$ and $\mathrm{N}: 5.4 \%$, obtained using an elemental analyzer (Perkin-Elmer $2400 \mathrm{CHN}$ ). The alkalinity of the suspension was measured at $325 \mathrm{mg}^{-1}$ of $\mathrm{CaCO}_{3}$, using standard method APHA SM 2320 (APHA, 1992). A strong pH-buffering effect was expected to be exhibited by the collected sludge.

\subsection{Pre-treatment}

Five pre-treatments were applied. These pretreatments not only released insoluble organic matter into water to increase the efficiency of fermentation, but also inactivated methanogenic bacteria in the substrate to reduce their consumption of hydrogen.

1) Ultrasonication-sonication tests were performed with the help of a cell-breaker (SONICATOR XL-2020, Heat System-Ultrasonics, 
Inc.) at a frequency of $20 \mathrm{kHz}$. Original sludge $(300 \mathrm{ml})$ was placed in a $500-\mathrm{ml}$ beaker with the ultrasonic probe positioned $2 \mathrm{~cm}$ above the bottom of the beaker. The sonication time was $20 \mathrm{~min}$ to release the insoluble organic matter from the solids (Chu et al., 2001).

2) Acidification-perchloric acid $\left(\mathrm{HClO}_{4}\right)$ was mixed with the sludge sample for $10 \mathrm{~min}$ to alter the $\mathrm{pH}$ of the suspension to 3 . Then, the sample was stored at $4{ }^{\circ} \mathrm{C}$ for $6 \mathrm{~h}$ (Jean et al., 2000).

3) Sterilization - samples of sludge were sterilized at $121{ }^{\circ} \mathrm{C}$ and $1.2 \mathrm{kgf} \mathrm{cm}^{-2}$ (Huxley Autoclave, HL-360) for $30 \mathrm{~min}$.

4) Methanogenic inhibitor-BESA $\left(\mathrm{C}_{2} \mathrm{H}_{4} \mathrm{BrO}_{3} \mathrm{SNa}\right.$, sodium 2-bromoethanesulfonate, Sigma, USA) has a chemical structure $\left(\mathrm{BrCH}_{2} \mathrm{CH}_{2} \mathrm{SO}_{3}^{-}\right)$that resembles that of the co-enzyme $\mathrm{M}\left(\mathrm{HSCH}_{2} \mathrm{CH}_{2} \mathrm{SO}_{3}^{-}\right)$, required for the methanogenic stage. It can thus inhibit the growth of methanogenic bacteria. Preliminary tests showed that a minimum dose of $1 \mathrm{M}$ of BESA was required to sufficiently inhibit the activity of methanogenic bacteria in the present sludge. This dose was applied to the original sludge at $35{ }^{\circ} \mathrm{C}$ to suppress the activity of the methanogenic bacteria.

5) Freezing and thawing - the sludge was frozen at $-17{ }^{\circ} \mathrm{C}$ for $24 \mathrm{~h}$ and then thawed for another $12 \mathrm{~h}$ in a water bath at $25{ }^{\circ} \mathrm{C}$ (Hung et al., 1997). The freezing and thawing released considerable amounts of insoluble organic matter, particularly polysaccharides, to water as the ice front moved (Hung et al., 1996).

The original and pre-treated sludges were the substrates used in the hydrogen fermentation tests.

\subsection{The inoculum}

The inoculum was isolated from the collected wastewater sludge. The applied procedures include: (i) sterilizing at $121{ }^{\circ} \mathrm{C}$ and $1.2 \mathrm{kgf} \mathrm{cm}^{-2}$ (Huxley Autoclave, HL-360) for $30 \mathrm{~min}$ to inactivate the methanogenic bacteria (Lay, 2000); (ii) adding $100 \mathrm{mM}$ of BESA to the sterilized sludge from step (i) for $24 \mathrm{~h}$ under anaerobic conditions; and (iii) isolating and purifying the incubated sludge in step (ii). Step (iii) include colonization of the incubated sludge on a gel-type reinforced clostridial medium for $72 \mathrm{~h}$, three-time isolation of strains by removing and incubating colonies on the agar and the final selection of the strains by preliminary hydrogen production tests. The strains with the highest hydrogen yields were used as the inoculum in this study. These strains were analyzed at the following steps: DNA extraction, PCR amplification of $16 \mathrm{~S}$ DNA gene, purification of PCR products, cycle sequencing, further purification and electrophoresis on the ABI Prism 377 DNA Sequencer. The sequence analysis of the $16 \mathrm{~S}$ rDNA in the inoculum showed that it is a member of the clostridia family, Clostridium bifermentans.

\subsection{Fermentation and testing}

Substrate $(45 \mathrm{ml}$; original or pre-treated) was mixed with $5 \mathrm{ml}$ of inoculum suspension and was anaerobically incubated at $35{ }^{\circ} \mathrm{C}$ in $125 \mathrm{ml}$ serum bottles without stirring or further addition of nutrients. The bottles were capped with butyl rubber stoppers and wrapped in aluminum foil to prevent photolysis of the substrate (Chang et al., 1996). Gas and liquor samples were extracted at 8 , $16,24,32,40,48,72$ and $96 \mathrm{~h}$ of fermentation. At each time and for each substrate (original or pretreated), three serum bottles were arbitrarily selected and their average of hydrogen concentrations was reported. After measurements, the selected samples were abandoned to prevent the introduction of possible errors due to sampling, including gas leakage. Seven batches, including over 189 bottles (six batches $\times$ nine intervals $\times$ three bottles per measurement) of samples, were prepared.

A GC-TCD (Shimadzu, GC-8A), equipped with a stainless column packed with Porapack Q (50/80 mesh) at $70{ }^{\circ} \mathrm{C}$ and a thermal-conductivity detector (TCD), measured the hydrogen and methane concentrations in the gas phase. The temperature of the injector and the detector of GC was maintained at $100{ }^{\circ} \mathrm{C}$. Nitrogen flowed at $20 \mathrm{ml}$ $\mathrm{min}^{-1}$ as the carrying gas. An integrator (HP3396 Series II) integrated the area under the peak of the effluent curve and quantified the gaseous concen- 
Table 1

Hydrogen productivities reported in literature works

\begin{tabular}{|c|c|c|c|c|c|c|c|c|}
\hline Author & Reactor type & Substrate & Seed & $\begin{array}{l}\text { Maximum yield } \\
\left(\mathrm{g} \mathrm{kg}^{-1} \mathrm{DS}\right)\end{array}$ & $\begin{array}{l}\text { Maximum yield } \\
\left(\mathrm{g} \mathrm{kg}^{-1} \mathrm{VSS}\right)\end{array}$ & $\begin{array}{l}\text { Maximum yield } \\
\left(\mathrm{g} \mathrm{kg}^{-1} \mathrm{COD}\right)\end{array}$ & $\begin{array}{l}\text { Maximum yield } \\
\left(\mathrm{g} \mathrm{kg}^{-1} \text { substrate }\right. \\
\text { consumed })\end{array}$ & $\begin{array}{l}\text { Specific rate of } \\
\text { hydrogen }\end{array}$ \\
\hline $\begin{array}{l}\text { Tanisho and } \\
\text { Ishiwata (1994) }\end{array}$ & Continuous reactor & Molasses & $\begin{array}{l}\text { Enterobacter } \\
\text { aeroenes }\end{array}$ & $20.8^{*}$ & $20.8^{\mathrm{a}}$ & 19.5 & $\begin{array}{l}27.8 \text { (based on } \\
\text { sucrose)* }\end{array}$ & $\begin{array}{l}4.13 \mathrm{~g} \mathrm{~kg}^{-1} \text { sugar } \\
\mathrm{h}^{-1}\end{array}$ \\
\hline $\begin{array}{l}\text { Tanisho and } \\
\text { Ishiwata (1995) }\end{array}$ & $\begin{array}{l}\text { Continuous reactor } \\
\text { with urethane foam } \\
\text { to support the flocs }\end{array}$ & Molasses & $\begin{array}{l}\text { Enterobacter } \\
\text { aeroenes }\end{array}$ & $15.6^{*}$ & $15.6^{\mathrm{a}}$ & 14.6 & $\begin{array}{l}38.9 \text { (based on } \\
\text { sucrose)* }\end{array}$ & $\begin{array}{l}1.3 \mathrm{~g} \mathrm{~kg}^{-1} \text { sugar } \\
\mathrm{h}^{-1}\end{array}$ \\
\hline $\begin{array}{l}\text { Kataoka et al. } \\
\text { (1997) }\end{array}$ & Continuous reactor & $\begin{array}{l}\text { Glucose and poly- } \\
\text { peptone }\end{array}$ & $\begin{array}{l}\text { Clostridium } \\
\text { butylicum }\end{array}$ & $24.44 *$ & $24.44^{\mathrm{a}}$ & 23.0 & NA & $\begin{array}{l}2.6 \mathrm{~g} \mathrm{H}_{2} \mathrm{~kg}^{-1} \text { glu- } \\
\text { cose } \mathrm{h}^{-1}\end{array}$ \\
\hline $\begin{array}{l}\text { Sparling et al. } \\
\text { (1997) }\end{array}$ & Serum bottles & Paper & $\begin{array}{l}\text { Clostridium } \\
\text { thermocellum }\end{array}$ & $0.50^{*}$ & NA & NA & NA & $0.11 \mathrm{~g} \mathrm{~kg}^{-1} \mathrm{DS} \mathrm{h}^{-1}$ \\
\hline $\begin{array}{l}\text { Sparling et al. } \\
\text { (1997) }\end{array}$ & Serum bottles & Paper & $\begin{array}{l}\text { Undefined } \\
\text { consortium }\end{array}$ & $1.50^{*}$ & NA & NA & NA & $\begin{array}{l}0.002 \mathrm{~g} \mathrm{~kg}^{-1} \mathrm{DS} \\
\mathrm{h}^{-1}\end{array}$ \\
\hline Lay et al. (1999) & Serum bottles & $\begin{array}{l}\text { Organic municipal } \\
\text { solid waste }\end{array}$ & $\begin{array}{l}\text { Sludge of } \\
\text { anaerobic digester }\end{array}$ & NA & $14\left(37{ }^{\circ} \mathrm{C}\right)^{*, \mathrm{~b}}$ & NA & NA & $\begin{array}{l}3.54 \mathrm{~g} \mathrm{~kg}^{-1} \text { VSS } \\
\mathrm{h}^{-1}\left(37{ }^{\circ} \mathrm{C}\right)\end{array}$ \\
\hline $\begin{array}{l}\text { Lin and Chang } \\
\text { (1999) }\end{array}$ & Continuous reactor & Glucose & $\begin{array}{l}\text { Consortium from } \\
\text { sewage digester }\end{array}$ & $19.0^{*}$ & $19.0^{\mathrm{a}}$ & 17.8 & 23.3 & $38 \mathrm{~g} \mathrm{~kg}^{-1} \mathrm{VSS} \mathrm{h}^{-1}$ \\
\hline Zhu et al. (1999) & $\begin{array}{l}\text { Batch reactor with } \\
\text { agar gel immobili- } \\
\text { zation }\end{array}$ & Tofu wastewater & $\begin{array}{l}\text { Immobilized } \\
\text { Rhodobacter } \\
\text { sphaeroides }\end{array}$ & $\begin{array}{l}19.3\left(30{ }^{\circ} \mathrm{C}\right) \\
\text { (based on carbo- } \\
\text { hydrate) }{ }^{*, \mathrm{~b}}\end{array}$ & $19.3\left(30{ }^{\circ} \mathrm{C}\right)^{\mathrm{a}, \mathrm{b}}$ & NA & NA & - \\
\hline Zhu et al. (1999) & $\begin{array}{l}\text { Batch reactor with } \\
\text { agar gel immobili- } \\
\text { zation }\end{array}$ & Glucose & $\begin{array}{l}\text { Immobilized } \\
\text { Rhodobacter } \\
\text { sphaeroides }\end{array}$ & $29.8\left(30 \quad{ }^{\circ} \mathrm{C}\right)^{*, \mathrm{~b}}$ & $29.8\left(30{ }^{\circ} \mathrm{C}\right)^{\mathrm{a}, \mathrm{b}}$ & $27.9\left(30{ }^{\circ} \mathrm{C}\right)^{\mathrm{b}}$ & NA & - \\
\hline Cheng et al. (2000) & Batch reactor & $\begin{array}{l}\text { Centrate of boiling } \\
\text { treated sludge }\end{array}$ & $\begin{array}{l}\text { Consortiums in } \\
\text { boiled treated } \\
\text { sludge }\end{array}$ & NA & NA & $1.42 *$ & NA & - \\
\hline Cheng et al. (2000) & Batch reactor & $\begin{array}{l}\text { Boiling treated } \\
\text { sludge }\end{array}$ & $\begin{array}{l}\text { Consortiums in } \\
\text { boiled treated } \\
\text { sludge }\end{array}$ & 1.03 & $1.44^{*}$ & 0.40 & NA & - \\
\hline $\begin{array}{l}\text { Huang et al. } \\
(2000)\end{array}$ & Batch reactor & $\begin{array}{l}\text { Waste activated } \\
\text { sludge }\end{array}$ & $\begin{array}{l}\text { Consortiums in } \\
\text { digested sludge }\end{array}$ & $0.16\left(36{ }^{\circ} \mathrm{C}\right)^{*, \mathrm{~b}}$ & NA & NA & NA & - \\
\hline Lay (2000) & Serum bottles & Starch & $\begin{array}{l}\text { Sludge from } \\
\text { anaerobic digester }\end{array}$ & 95.6 & $95.6^{\mathrm{a}}$ & $102\left(37{ }^{\circ} \mathrm{C}\right)^{*, \mathrm{~b}}$ & NA & $\begin{array}{l}6.54 \mathrm{~g} \mathrm{~kg}^{-1} \mathrm{VSS} \\
\mathrm{h}^{-1}\end{array}$ \\
\hline $\begin{array}{l}\text { Mizuno et al. } \\
(2000 \mathrm{a})\end{array}$ & $\begin{array}{l}\text { Continuous reactor } \\
\text { without nitrogen } \\
\text { sparging }\end{array}$ & Glucose & Clostridium sp. & $9.3^{*}$ & $9.3^{\mathrm{a}}$ & 8.7 & $9.4^{*}$ & $\begin{array}{l}6.84 \mathrm{~g} \mathrm{~kg}^{-1} \text { biomass } \\
\mathrm{h}^{-1}\end{array}$ \\
\hline $\begin{array}{l}\text { Mizuno et al. } \\
(2000 \mathrm{a})\end{array}$ & $\begin{array}{l}\text { Continuous reactor } \\
\text { with nitrogen } \\
\text { sparging }\end{array}$ & Glucose & Clostridium sp. & $15.8^{*}$ & $15.8^{\mathrm{a}}$ & 14.8 & $15.9^{*}$ & $\begin{array}{l}14.9 \mathrm{~g} \mathrm{~kg}^{-1} \text { biomass } \\
\mathrm{h}^{-1}\end{array}$ \\
\hline
\end{tabular}


Table 1 (Continued)

\begin{tabular}{|c|c|c|c|c|c|c|c|c|}
\hline Author & Reactor type & Substrate & Seed & $\begin{array}{l}\text { Maximum yield } \\
\left(\mathrm{g} \mathrm{kg}^{-1} \mathrm{DS}\right)\end{array}$ & $\begin{array}{l}\text { Maximum yield } \\
\left(\mathrm{g} \mathrm{kg}^{-1} \text { VSS) }\right.\end{array}$ & $\begin{array}{l}\text { Maximum yield } \\
\left(\mathrm{g} \mathrm{kg}^{-1} \mathrm{COD}\right)\end{array}$ & $\begin{array}{l}\text { Maximum yield } \\
\left(\mathrm{g} \mathrm{kg}^{-1} \text { substrate }\right. \\
\text { consumed) }\end{array}$ & $\begin{array}{l}\text { Specific rate of } \\
\text { hydrogen }\end{array}$ \\
\hline $\begin{array}{l}\text { Mizuno et al. } \\
(2000 \mathrm{~b})\end{array}$ & Batch reactor & $\begin{array}{l}\text { Bean curd manu- } \\
\text { facturing waste }\end{array}$ & $\begin{array}{l}\text { Anaerobic } \\
\text { microflora }\end{array}$ & 5.2 & 6.3 & NA & $\begin{array}{l}28.22 \text { (based on } \\
\text { hexose)* }\end{array}$ & - \\
\hline Bai et al. (2001) & Serum bottles & Peptone & $\begin{array}{l}\text { Boiling treated } \\
\text { sludge from UASB }\end{array}$ & $1.98\left(35{ }^{\circ} \mathrm{C}\right) *, \mathrm{~b}$ & $1.98\left(35{ }^{\circ} \mathrm{C}\right)^{\mathrm{a}, \mathrm{b}}$ & $0.69\left(35{ }^{\circ} \mathrm{C}\right)^{\mathrm{b}}$ & NA & - \\
\hline Lay (2001) & Serum bottles & $\begin{array}{l}\text { Crystalline cellu- } \\
\text { lose }\end{array}$ & $\begin{array}{l}\text { Sludge from } \\
\text { anaerobic digester }\end{array}$ & $4.36^{*}$ & $4.36^{\mathrm{a}}$ & 4.0 & NA & $1.5 \mathrm{~g} \mathrm{~kg}^{-1} \mathrm{VSS} \mathrm{h}^{-}$ \\
\hline Liang et al. (2001) & Serum bottles & Peptone & $\begin{array}{l}\text { UASB sludge } \\
\text { inhibited by } \\
\text { chloroform }\end{array}$ & $2.96^{*}$ & $2.96^{\mathrm{a}}$ & 1 & NA & - \\
\hline Liang et al. (2001) & Serum bottles & Glucose & $\begin{array}{l}\text { UASB sludge } \\
\text { inhibited by } \\
\text { chloroform }\end{array}$ & $9.92^{*}$ & $9.92^{\mathrm{a}}$ & 9.3 & NA & - \\
\hline Lin et al. (2001) & Continuous reactor & $\begin{array}{l}\text { Alkaline-hydro- } \\
\text { lyzed waste acti- } \\
\text { vated sludge }\end{array}$ & $\begin{array}{l}\text { Boiling treated } \\
\text { sludge from sewage } \\
\text { wastewater plant }\end{array}$ & NA & NA & NA & $\begin{array}{l}1.7 \text { (based on } \\
\text { TCOD removed)* }\end{array}$ & $\begin{array}{l}0.05 \mathrm{~g} \mathrm{~kg}^{-1} \text { TCOD } \\
\mathrm{h}^{-1}\end{array}$ \\
\hline
\end{tabular}

a All substrates are assumed volatile and ash-free.

b The hydrogen was assumed to be collected $1 \mathrm{~atm}$.

* These values were reported in the original work. 
trations. Repeated measurements showed that the determined hydrogen and methane contents included a maximum relative error of 15 and $10 \%$, respectively. The hydrogen content in the anaerobic glove box was also measured and was subtracted from the hydrogen concentrations obtained in the serum bottles. The oxidative and reductive potential (ORP) and the $\mathrm{pH}$ value of the sludge were measured using an ORP-pH meter (HI 9017 Hanna). The $\zeta$ potentials and the size distributions of the flocs of sludge were determined using a $\zeta$ meter (Zetameter, Malvern) and a particle sizer (Mastersizer 2000, Malvern), respectively.

\section{Results and discussion}

\subsection{Hydrolyzing organic matter}

Fig. 1 plots the time evolution of SCOD for the fermented sludge. These data are normalized according to the chemical oxygen demand for the original sludge, $\mathrm{COD}_{0} \quad\left(=24800 \mathrm{mg} \mathrm{l}^{-1}\right)$. Although some data are scattered, two points are notable. Firstly, the soluble COD of the original sludge is only $1.5 \%$ of $\mathrm{COD}_{0}$. All pre-treatments markedly increase this ratio to $4-5 \%$, an enhancement of $150-250 \%$. This finding is consistent with the findings of Lee and Mueller (2001). Secondly,

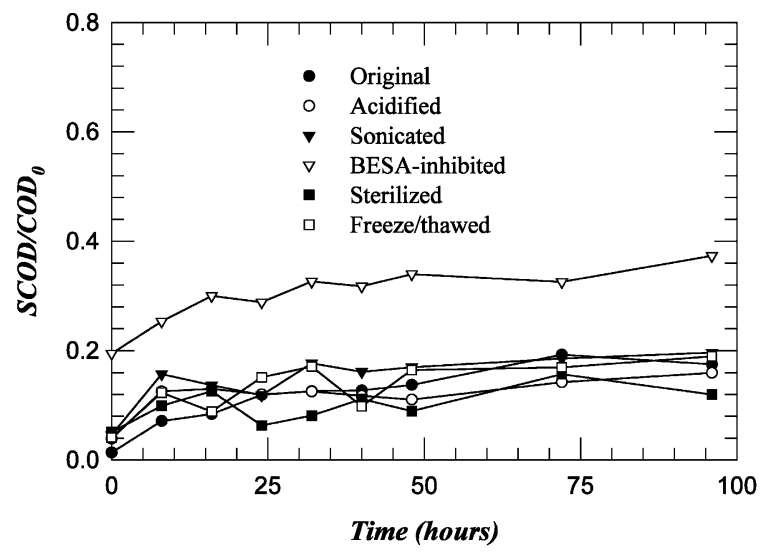

Fig. 1. The temporal variation of $\mathrm{SCOD} / \mathrm{COD}_{0}$ for sludge samples. the SCOD of the sludge samples increases to 8$16 \%$ after testing for $8 \mathrm{~h}$.

\subsection{Hydrogen production}

Fig. 2 plots the quantity of produced hydrogen in the serum bottle obtained from GC-TCD tests. Contrary to the results obtained with a 66-h time lag by Cheng et al. (2000) for anaerobic fermentation, this work found a negligible time lag, which may be attributable to the fact that the inoculum was derived directly from the substrate sludge. The hydrogen concentration in the gas phase follows an increasing-decreasing curve, with a peak at 8 $24 \mathrm{~h}$, implying that a certain quantity of produced hydrogen has been in some way 'consumed'. Cheng et al. (2000) reported a similar 'hydrogen consumption' phase during anaerobic fermentation.

Fig. 3 presents the specific hydrogen yield based

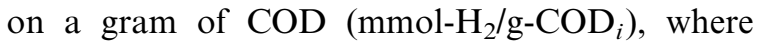
$\mathrm{COD}_{i}$ is the COD of the substrate prior to testing, which is the inoculum + original sludge or + pretreated sludge. Table 2 lists the $\mathrm{COD}_{i}$ values for all pre-treated samples prior to fermentation. In fact, all $\mathrm{COD}_{i} \mathrm{~s}$ are close to $\mathrm{COD}_{0}$, but with certain data fluctuation. A large data fluctuation is commonly noted for sludge tests since the collected sample is heterogeneous in nature.

As Fig. 4 shows, the specific hydrogen yield could reach $0.6 \mathrm{mmol} \mathrm{g}^{-1}-\mathrm{COD}_{i}$ for the original

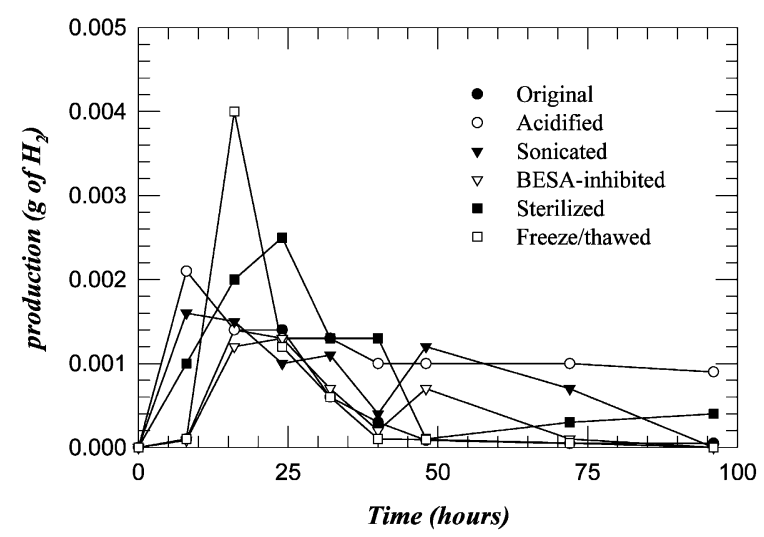

Fig. 2. The hydrogen production amount versus time plot. 


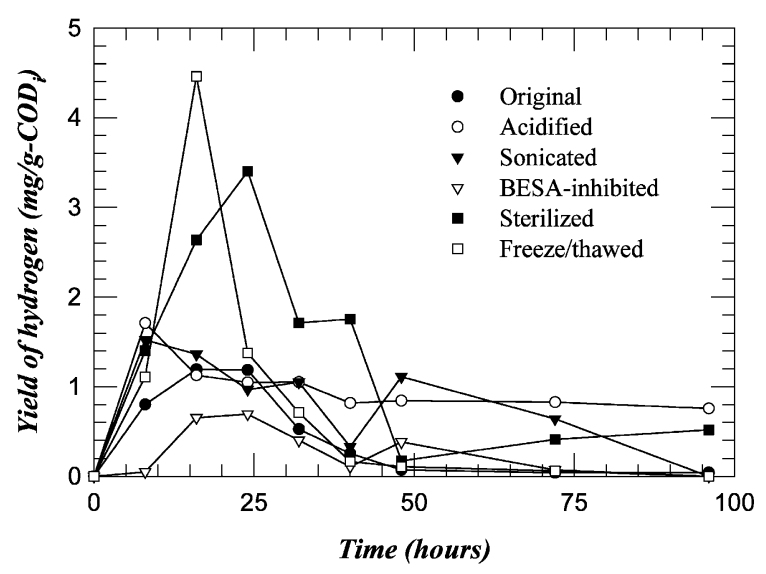

Fig. 3. The hydrogen yield versus time plot.

Table 2

The $\mathrm{COD}_{i}$ for various samples

\begin{tabular}{ll}
\hline Sample & $\mathrm{COD}_{i}\left(\mathrm{mg} \mathrm{l}^{-1}\right)$ \\
\hline Original+inoculum & 27000 \\
Sonicated + inoculum & 26200 \\
Acidified + inoculum & 24000 \\
Sterilized + inoculum & 25200 \\
Freeze/thawed +inoculum & 30000 \\
BESA-added +inoculum & 25600 \\
\hline
\end{tabular}

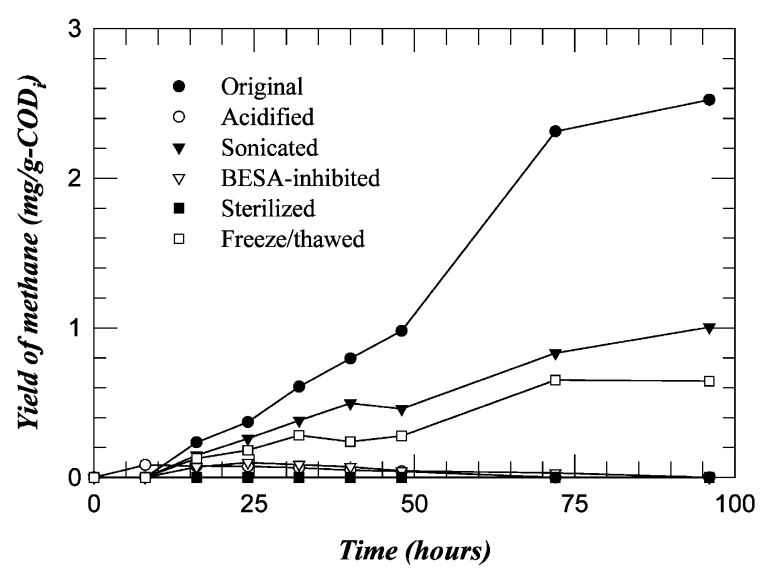

Fig. 4. The methane yield versus time plot. sludge, equivalent to $0.9 \mathrm{mmol} \mathrm{g}^{-1}$-dried sludge in the system of interest. This value far exceeds that

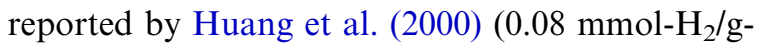
dried sludge). Meanwhile, freezing and thawing and sterilization markedly increase the specific hydrogen yield from $\approx 0.6$ for the original sludge

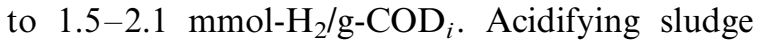
did not significantly promote the production of bio-hydrogen. Furthermore, adding BESA and ultrasonication reduced the bio-hydrogen yield. The SCODs for all pre-treated sludge were higher than the original sludge (Fig. 1). Hence, not all organic matter released from the sludge is readily anaerobically fermented to hydrogen.

\subsection{Methane production}

Fig. 4 presents the amount of accumulated methane gas in the serum bottles with time. The amount of methane monotonically increases during fermentation with the magnitude of methane amount in the order, original $>$ ultrasonicallytreated or freeze/thawed $>$ acidified or BESA-added $>$ sterilized sludge. The amounts of methane produced after $96 \mathrm{~h}$ from the original $(0.26 \mathrm{mmol}-$ $\mathrm{CH}_{4} /$ g-dried sludge) and sonicated samples are 0.26 and $0.063 \mathrm{mmol}-\mathrm{g}-\mathrm{CH}_{4} / \mathrm{g}$-dried sludge, respectively. These values are much lower than those obtained by Chu et al. (2002b): 1.6 and $5 \mathrm{mg}-\mathrm{CH}_{4} /$ g-dried sludge, respectively, when methanogenic bacteria were externally seeded at the start of the digestion test. The pretreatments effectively deactivated most methanogenic bacteria in the substrate in this study. The hydrolyzed organic matter (increased COD in Fig. 1) was not effectively converted to methane gas by the inoculum.

BESA effectively suppressed methane production to $\approx 50 \%$ of the original sludge. However, hydrogen production was not enhanced. This methanogenic inhibitor, at a high concentration of $1 \mathrm{M}$, might disrupt the fermentation pathway by Clostridium sp., or might not really be able to block out all hydrogen-consuming pathways taken by other bacteria, including sulfur-reducing bacteria. 


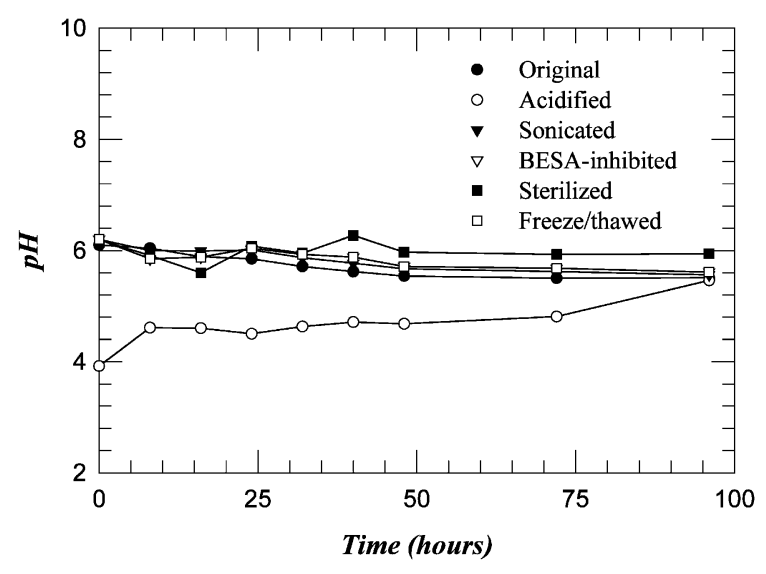

Fig. 5. The evolution of $\mathrm{pH}$ value during anaerobic fermentation.

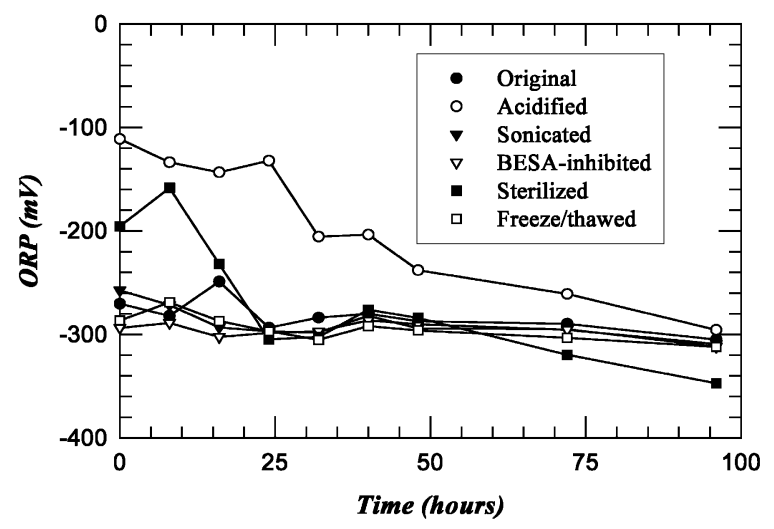

Fig. 6. The evolution of ORP value during anaerobic fermentation.

\subsection{Species-dependent fermentation efficiency}

Figs. 5 and 6 plot $\mathrm{pH}$ and ORP for the suspension during the fermentation test, respectively. For all samples, the $\mathrm{pH}$ value slowly approaches 5-5.5 and ORP approaches about $300 \mathrm{mV}$. The $\zeta$ potential and the floc size of the fermented samples (data not shown) were also measured. All samples, after $24 \mathrm{~h}$ of fermentation, exhibited a $\zeta$ potential between -13 and $-17 \mathrm{mV}$ and a size between 60 and $70 \mu \mathrm{m}$, except in the freeze/thawed case. Although the sludge samples yielded different hydrogen or methane productivities, they were converted to entities of similar size and surface charge. Meanwhile, the suspension approached a similarly reductive environment. The changes in environmental factors were insignificant. Jones and Woods (1986) suggested that because of the accumulation of fatty acid in suspension, the fall in $\mathrm{pH}$ during fermentation prevented the production of hydrogen from biomass. This suggestion does not apply in this study because of the strong buffering capacity of the sludge. Some of the consumed hydrogen was transformed into methane. However, the 'consumption' of formed hydrogen (Fig. 3) and the production of methane (Fig. 4) are not correlated. For instance, the peak hydrogen productivity for freeze/thawed sludge, occurring after $16 \mathrm{~h}$ of fermentation, was $\approx 4.4 \mathrm{mg} / \mathrm{g}-\mathrm{COD}_{i}$. This amount of hydrogen was mostly consumed at hour 40, meanwhile, the corresponding methane production was only $0.28 \mathrm{mg} / \mathrm{g}-\mathrm{COD}_{i}$. The methaneproducing pathway can therefore partially account for the hydrogen-consuming phase.

The various hydrogen yields following various pre-treatment processes imply that not all the released COD are ready for hydrogen formation. The species released from the sludge should correspond to the observed differences in biohydrogen yields since the changes in all environmental factors were minimal. Hung et al. (1996) showed that freezing and thawing released considerable amounts of cellulose but retained most lipids or protein on the solids phase. Different pretreatments may thus 'fractionate' the components in the solids and the aqueous phase, thereby modifying the hydrogen productivity. For example, the increase in the amount of cellulose in suspension after freezing and thawing may correspond to the increase in hydrogen yield. However, ultrasonication may release sufficiently large amounts of undesired compounds that suppress the fermentation. Releasing a fraction of COD to prepare for hydrogen production is essential to facilitate efficient fermentation. Further works are now in progress to elucidate this point.

\section{Conclusions}

This work is the first systematic study of the use of $C$. bifermentans to produce hydrogen from 
wastewater sludge. The hydrogen yields reported in the literature ranged from 4.6 to $15 \mathrm{mmol}-\mathrm{H}_{2} / \mathrm{g}$ dried solids (DS) for fermenting glucose-containing solution (Zhu et al., 1999; Lin and Chang, 1999; Mizuno et al., 2000a; Liang et al., 2001) or $1-1.5 \mathrm{mmol}^{-\mathrm{H}_{2}} / \mathrm{g}$-DS from the protein-containing solution (Bai et al., 2001; Liang et al., 2001). Meanwhile, the hydrogen yield by anaerobically fermenting wastewater sludge is rather low at $\approx$ $0.08 \mathrm{mmol}^{-\mathrm{H}_{2}} / \mathrm{g}$-dried solids (Huang et al., 2000). We demonstrated a hydrogen yield for the original wastewater sludge up to $0.9 \mathrm{mmol}_{-} \mathrm{H}_{2} / \mathrm{g}$-dried solids, close to that fermented from protein-containing wastewater. The effects of five different pre-treatments, ultrasonication, acidification, sterilization, freezing and thawing, and adding methanogenic inhibitor, on the hydrogen yield were investigated. Freezing and thawing and sterilization markedly increased the specific hydrogen yield to $1.5-2.1 \mathrm{mmol}-\mathrm{H}_{2} / \mathrm{g}-\mathrm{COD}$. This yield exceeds that obtained from thermally boiled sludge by Cheng et al. (2000) (0.7 mmol- $\left.\mathrm{H}_{2} / \mathrm{g}-\mathrm{COD}\right)$. However, adding methanogenic inhibitor or performing ultrasonication reduced bio-hydrogen yield.

The hydrogen accumulation curve presents increasing-decreasing characteristics. After the peak is reached, a particular amount of methane is formed. No clear correlation exists between the reduction in the amount of produced hydrogen and the amount of methane converted from produced hydrogen, implying that only some hydrogen was converted into methane. Pre-treatments effectively released insoluble organic matter into water. Furthermore, the soluble chemical oxygen demand (SCOD) increased and approached a plateau after the first $8 \mathrm{~h}$ of fermentation of all samples. Examining the environmental factors revealed that changes in $\mathrm{pH}, \zeta$ potential or floc size did not relate to the observed consumption of hydrogen. Thus, not all released COD is ready for hydrogen formation.

\section{References}

Adams, M.W.W., Stiefel, E.I., 1998. Biological hydrogen production: not so elementary. Science 282, 1842-1843.
Siegelman, H.W., Kycia, J.H., 1978. Algal biliproteins. In: Hellebust, J.A., Craigie, J.S. (Eds.), Handbook of Psychological Methods, Physiological and Biochemical Methods. Cambridge University Press, Cambridge, pp. 71-79.

Bai, M.D., Cheng, S.S., Tseng, I.C., 2001. Biohydrogen produced due to peptone degradation by pretreated seed sludge. The IWA Asia-Pacific Regional Conference (WaterQual 2001), Fukuoka, Japan.

Bolliger, R., Zürrer, H., Bachofen, R., 1985. Photoproduction of molecular hydrogen from wastewater of a sugar refinery by photosynthetic bacteria. Appl. Microbiol. Biotechnol. $23,147-151$.

Chang, B.V., Zheng, J.X., Yuan, S.Y., 1996. Effects of alternative electron donors, acceptors and inhibitors on PCP dechlorination in soil. Chemosphere 33, 313-320.

Cheng, S.S., Bai, M.D., Chang, S.M., Wu, K.L., Chen, W.C., Chen, W.C., 2000. Studies on the feasibility of hydrogen production hydrolyzed sludge by anaerobic microorganisms. The Twenty-fifth Wastewater Technology Conference, Yunlin, Taiwan (in Chinese).

Chu, C.P., Feng, W.H., Chang, B.V., Lee, D.J., 1999. Reduction in microbial density level in wastewater activated sludge via freezing and thawing. Water Res. 33, 3532-3535.

Chu, C.P., Lee, D.J., Chang, B.V., Liao, C.S., 2001. Observations on changes in ultrasonically treated waste activated sludge. Water Res. 35, 1038-1046.

Chu, C.P., Lin, W.W., Lee, D.J., Chang, B.V., Peng, X.F., 2002a. Thermal treatment of waste activated sludge using liquid boiling. J. Environ. Eng. ASCE 128, 1100-1103.

Chu, C.P., Lee, D.J., Chang, B.-V., You, C.S., 2002b. 'Weak' ultrasonic pretreatment on anaerobic digestion of polyelectrolyte flocculated activated biosolids. Water Res. 36, $2681-$ 2688.

Gurijala, K.R., Sa, P., Mormile, M.R., 2000. Relative significance of environmental factors affecting hydrogen production from landfilled refuse samples. Waste Manage. Res. 18, 453-461.

Guwy, A.J., Hawkes, F.R., Hawkes, D.L., Rozzi, A.G., 1997. Hydrogen production in a high rate fluidized bed anaerobic digester. Water Res. 21, 1291-1298.

Huang, C.H., Lin, H.Y., Tsai, Y.Y., Hsie, Y.K., 2000. The preliminary studies of hydrogen production from anaerobic digestion with different substrates and cultivations. The Twenty-fifth Wastewater Technology Conference, Yunlin, Taiwan (in Chinese).

Hung, W.T., Chang, I.L., Hong, S.G., Young, S.D., Chen, G.W., Lee, D.J., 1996. Floc migration and chemical compositions changes in a freezing chamber. J. Environ. Sci. Health A31, 1053-1066.

Hung, W.T., Feng, W.H., Tsai, I.H., Lee, D.J., Hong, S.G., 1997. Unidirectional freezing of waste activated sludge: radial freezing versus vertical freezing. Water Res. 31, 2219-2228.

Jean, D.S., Chang, B.V., Liao, G.S., Tsou, G.W., Lee, D.J., 2000. Reduction of microbial density level in sewage sludge through $\mathrm{pH}$ adjustment and ultrasonic treatment. Water Sci. Technol. 42 (9), 97-102. 
Jones, D.T., Woods, D.R., 1986. Acetone-butanol fermentation revisited. Microbiol. Rev. 50, 484-524.

Kataoka, N., Miya, A., Kiriyama, K., 1997. Studies on hydrogen production by continuous culture system of hydrogen-producing anaerobic bacteria. Water Sci. Technol. 36 (6-7), $41-47$.

Lay, J.J., 2000. Modeling and optimization of anaerobic digested sludge converting starch to hydrogen. Biotechnol. Bioeng. 68, 269-278.

Lay, J.J., 2001. Biohydrogen generation by mesophilic anaerobic fermentation of microcrystalline cellulose. Biotechnol. Bioeng. 74, 280-287.

Lay, J.J., Lee, Y.J., Noike, T., 1999. Feasibility of biological hydrogen production from organic fraction of municipal solid waste. Water Res. 33, 2579-2586.

Lee, D.J., Mueller, J.A., 2001. Preliminary treatments. In: Spinosa, L., Vesilind, P.A. (Eds.), Sludge into Biosolids. International Water Association, UK.

Liang, T.M., Wu, K.L., Cheng, S.S., 2001. Hydrogen production of chloroform inhibited granular sludge. The IWA Asia-Pacific Regional Conference (WaterQual 2001), Fukuoka, Japan.

Lin, C.Y., Chang, R.C., 1999. Hydrogen production during the anaerobic acidogenic conversion of glucose. J. Chem. Technol. Biotechnol. 74, 498-500.

Lin, H.Y., Tsai, Y.Y., Wu, R.H., 2001. Study of hydrogen production from the anaerobic digestion of hydrolyzed biological sludge. The Twenty-sixth Wastewater Technology Conference, Kaohsiung, Taiwan (in Chinese).

Liu, S.J., Yang, W.F., Zhou, P.Q., 1995. The research on hydrogen production from the treatment of bean products wastewater by immobilized photosynthetic bacteria. Environ. Sci. 16, 42-44.

Mizuno, O., Dinsdale, R., Hawkes, F.R., Hawkes, D.L., Noike, T., 2000a. Enhancement of hydrogen production from glucose by nitrogen gas sparging. Biores. Technol. 73, 5965 .

Mizuno, O., Ohara, T., Shinya, M., Noike, T., $2000 \mathrm{~b}$. Characteristics of hydrogen production from bean curd manufacturing waste by anaerobic microflora. Water Sci. Technol. 42 (3-4), 345-350.

Sparling, R., Risbey, D., Poggi-Varaldo, H.M., 1997. Hydrogen production from inhibited anaerobic composters. Int. J. Hydro. Energy 22, 563-566.

Tanisho, S., Ishiwata, Y., 1994. Continuous hydrogen production from molasses by the bacterium Enterobacter aerogenes. Int. J. Hydro. Energy 19, 807-812.

Tanisho, S., Ishiwata, Y., 1995. Continuous hydrogen production from molasses by fermentation using urethane foam as a support of flocks. Int. J. Hydro. Energy 20, $541-545$.

Tanisho, S., Kuromoto, M., Kadokura, N., 1998. Effect of $\mathrm{CO}_{2}$ removal on hydrogen production by fermentation. Int. J. Hydro. Energy 23, 559-563.

Ueno, Y., Otauka, S., Morimoto, M., 1996. Hydrogen production from industrial wastewater by anaerobic microflora in chemostat culture. J. Ferment. Bioeng. 82, 194-207.

Zhu, H., Suzuki, T., Tsygankov, A.A., Asada, Y., Miyake, J., 1999. Hydrogen production from tofu wastewater by Rhodobacter sphaerodies immobilized in agar gels. Int. J. Hydro. Energy 24, 305-310. 